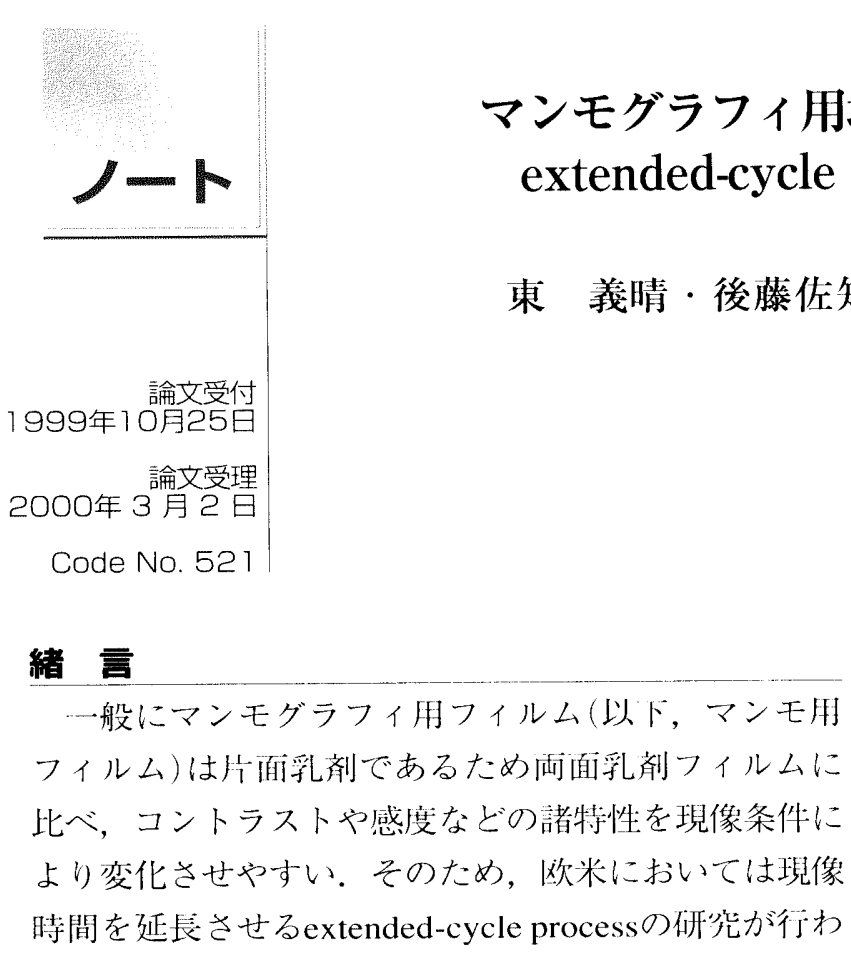

\author{
岡山大学医学部保健学科
}

れたは・・・方，わが国ではextended-cycle processに関 する詳細な研究報告が見当たらない。そこで，文献7） において日本で使用されている標準処理用のマンモ用 フィルムにextended-cycle processを適用し，その特性 曲線の変化について報告した。本論文では引き続き， X線写真のノイズ特性を取り上げた。

\title{
Basic Study of the Effect of the Extended-cycle Process on Mammographic Screen/Film Systems: Granularity
}

\section{YOSHIHARU AZUMA, SACHIKO GOTO, TOSHINORI MARUYAMA, YOSHITADA NAKAGIRI, and KATSUHIKO SUGITA}

\author{
Faculty of Health Sciences, Okayama University Medical School \\ Received oct. 25, 1999; Revision accepted March 2, 2000; Code No. 521
}

\section{Summary}

With single-emulsion films like those used in screen/film mammography, if the developing temperature is higher and/or the processing time is longer than recommended (i.e., extended-cycle process), film speed and/or film contrast are effectively increased. However, it can also be expected that radiographic noise will be increased by the extended-cycle process. Therefore, film graininess and radiographic mottle were investigated with standard-and extended-cycle processes in four single-screen/single-emulsion film systems for mammography, the Konica M-150/New CM, Fuji UM MAMMO Fine/UM-MA HC, Kodak MinR 2000/Min-R 2000, and Kodak Min-R Medium/Min-R M. Investigation was carried out by measurement of the Wiener spectrum (WS). Results showed that the WS of film graininess increased in all films. The increase was greatest in Min- $\mathrm{M} \mathrm{M}$, and the rate of increase at 2.0 cycles $/ \mathrm{mm}$ was 1.67 or more. The film showing the smallest increase was UM-MA HC, for which the rate of increase was 1.03-1.21. There were cases in which the spatial frequency at a 50 percent contribution rate of film graininess to radiographic mottle changed to a low spatial frequency. When only the increase in WS of radiographic mottle was examined, the increase was greatest in Min-R Medium/Min-R M, and the rate of increase at 2.0 cycles/mm was 1.65 or more. Min-R 2000/Min-R 2000 showed the least increase, and the rate of increase was 1.12-1.24. Increases in WS values were larger at $0.1-0.5 \mathrm{cycle} / \mathrm{mm}$ than at 2.0 cycles $/ \mathrm{mm}$ when investigating the influence of trend using film graininess, and roller marks and so on could not be specified as a cause.

Key words: Mammography, Screen/film system, Extended-cycle process, Granularity, Wiener spectrum 
よく知られているように, RossmannはX線写真の粒 状度 (以下, $X$ 線写真モトル)はスクリーンモトル (量子 モトル＋増感紙の構造モトル)拉よ゙フィルム粒状度 から構成されることを示した ${ }^{8)}$. それに基づくと，コ ントラストや感度が上昇するextended-cycle process 場合, modulation transfer function(MTF) が高い低空 間周波数域では，おもに量子モトルの増加によりX線 写真モトルが増加することは容易に推察できる。ま た，処理時間を標準より延長することにより，現像銀 の成長過程などが影響を受け，フィルム粒状度が変化 する可能性が考えられる．特にMTFの低下する高空間 周波数域では，相対的にフィルム粒状度の占める割合 が高くなるためその変化を調べてみる必要がある．欧 米の研究報告ではroot mean square (RMS) 粒状度によ る評価のみであるが, extended-cycle processによりX 線写真の粒状性が多少悪化する報告がされている21.

また実験を行うにあたり，どのようなextendedcycle processの条件を選択するかが問題になるが, そ の結論を得るためには物理的画質特性だけでなく，視 覚評価も必要になる。 その前段階である基礎的なデー 夕収集を目的としてextended-cycle processの条件を， 低温長時間，高温長時間，さらにそれらと標準処理の ほぼ中間になるような温度，処理時間の3 種類に設定 した、そして, extended-cycle processがX線写真のノ イズ特性に与える影響についてWiener spectrum(以 下，WS）の測定により調べたので報告する。

\section{1. 使用機材および方法}

\section{1-1 使用機材 \\ マンモ用X線撮影装置：}

Model MGU-01 (Mo target / Mo filter) (東芝・東芝メディカル株式会社製)

$\begin{array}{ll}\text { 自動現像機 } & : \mathrm{KX}-170 \mathrm{~B} \\ \text { 温度調節 } & : 25 \sim 45^{\circ} \mathrm{C} \\ \text { 処理時間 } & : 45 \sim 210 \mathrm{~s} \text { (無段階可変) } \\ \text { 現像タンク容量 } & : 7 l \\ \text { 現像液 } & : \mathrm{XD}-90 \mathrm{C} \\ \text { 定着液 } & : \mathrm{XF}-\mathrm{SR} \cdot \mathrm{C} \\ \text { 濃度計 } & : \mathrm{PDA}-15 \\ \text { マイクロデンシトメータ } & : \text { PDM-5B }\end{array}$

(以上，コニカ株式会社製)

増感紙/フィルム：

M-150/New CM (コニカ株式会社 製)，UM MAMMO Fine/UM-MA HC （富士メデイカルシステム株式会社 製)，Min-R 2000/Min-R 2000，MinR Medium/Min-R M（日本コダック株 式会社製）

\section{1-2 実験方法}

まず，フィルム粒状度は，増感紙とフィルム間に空 隙を設けて露光することにより，量子モトルや増感紙 の構造モトルを暈かし除去した試料から求めることが できる8). そこで, 3 社 4 種類のマンモ用フィルムに 対し，フィルムと増感紙を $15 \mathrm{~mm}$ 離して保持できるぺ 一パーカセッテを用いてフィルム粒状度用の試料を作 成した9)。さらに，スクリーンモトルおよびフィルム 粒状度を含むX線写真モトルを測定するため, 真空力 セッテを用いてフィルムと増感紙を密着させ試料を作 成した。また，American College of Radiology (ACR) のプログラムによる画質管理やTannerらの報告 ${ }^{10)} に よ$ ると，構造が認識できる最低濃度は 0.8 , マンモグラ フィの平均濃度は1.3であることから, 試料濃度をそ れらに合わせ，誤差が土0.02となるよう撮影条件を調 整した。その際，ヒール効果の影響を少なくして，で きるだけ均一な試料濃度の面積を広く得るため, 焦点 ーフィルム間の距離を約 $250 \mathrm{~cm}$ に設定するとともに， カセッテを管球の長軸に対して角度(約 5 度)をつけて 保持した。管電压は $28 \mathrm{kV}$ と, 使用した装置の通常 の撮影距離 $(60 \mathrm{~cm})$ では, 線質 (第一半価層) は $0.31 \mathrm{mmAl}$ であ。試料作成においては, 焦点一フィ ルム間の距離を約 $250 \mathrm{~cm}$ に設定したため線質は $0.41 \mathrm{mmAl}$ となった. extended-cycle process $の$ 条件, すなわち現像温度一処理時問は，まず低温長時間を想 定して $30^{\circ} \mathrm{C}-210 \mathrm{~s}$ とたた。 また，温度，処理時間の上 限值として $34^{\circ} \mathrm{C}-210 \mathrm{~s}$, さらにそれらと標準処理の中 間の温度，処理時間になる $32^{\circ} \mathrm{C}-150$ sをextendedcycle processの条件に選んだ. 使用した自動現像機の 現像のみの時間, すなわちフィルムが現像タンクに入 り始めてから, 出始めるまでの時間は, 処理時間90, 150，210sに対し，実測值でそれぞれ21，32，48sであ る.なお，標準処理条件 $34^{\circ} \mathrm{C}-90$ sにおける濃度 1.30 各フィルムの露光条件は, 40〜 60mAsであり, これは RMI 165 ファントム (GAMMEX RMI社, 圧迫乳房厚 $5 \mathrm{~cm}$ 相当で，脂肪組織 $50 \%$ ，乳腺組織 50\%をシミュ レートしている)を使用して，グリッド(+)で撮影する 条件にほぼ相当する。また, extended-cycle processの 露光条件を標準処理を基準に相対値としてTable 1 に示 ᄒ.

以上の試料濃度, 現像条件の異なるフィルム粒状度 およびX線写真モトル用の各試料を, マイクロデンシ トメータによりスリット幅 $10 \mu \mathrm{m}$, 高さ $1 \mathrm{~mm}$ で走查し て，40万点の濃度データをサンプリングした。さら に，高速フーリエ変換を行いWSを計算したが，その 際，Qファクタ補正処理およびトレンド処理 $($ 移動平 均トレンド除去法：1000)を行った11,12). 


\section{2. 結 果}

\section{2-1 フィルム粒状度}

Fig. 1〜4に標準処理およびextended-cycle processによるフィルム粒 状度のWS (以下，WSif) ，後述する X線写真モトルの結果も合わせて, フィルム (システム)ごとに示す。さ らに，空間周波数 2.0 cycles $/ \mathrm{mm}$ にお いて，標準処理の值を基準にしてextended-cycle process $の W S_{\text {f }}$ 值を増加率 で表すデータ整理を行いFig. 5に示し た。その際，試料濃度(以下，“D=” と表示)別に分け，グラフの横軸を処 理時間，縦軸を現像温度として， で表したマーカの直径に増加率を対 応させた。なお，増加傾向が分かり やすいように, extended-cycle process ではない30 $\mathrm{C}-90 \mathrm{~s}$ の増加率を○で表 示するとともに，標準処理のWS 值 $\left(\mathrm{mm}^{2}\right)$ を付け加えた。まず，Fig. 1に 示したNew CMでは，最も大きな影 響が考えられる $34^{\circ} \mathrm{C}-210$ に拈いて $\mathrm{WS}_{\mathrm{f}}$ は最大になり，Fig. 5に示した増 加率は， $1.60(\mathrm{D}=0.8), 1.76(\mathrm{D}=1.3)$ になった。次にUM-MA HCでは， Fig. 2に示したように増加は少なく， Fig. 5に示した増加率は, 最大1.16 $\left(\mathrm{D}=0.8,34^{\circ} \mathrm{C}-210 \mathrm{~s}\right), 1.21(\mathrm{D}=1.3$, $\left.32^{\circ} \mathrm{C}-150 \mathrm{~s}\right) に$ 留まった。また，Fig. 3のMin-R 2000では, extended-cycle processの各值は接近し, Fig. 5に示し た増加率は，1.39〜1.62( $\mathrm{D}=0.8)$, 1.25〜 $1.38(\mathrm{D}=1.3)$ の範囲であった。 Fig. 4のMin-R Mでは， 4 種類のフィ ルムの中で最も増加が著しくFig. 5に 示すように1.67 (D=1.3，32 $\mathrm{C}-150 \mathrm{~s})$ 以上の増加率になった。なお, 以上 のように増加率すなわち相対値で評 価してきたが，絶対值はいずれのフ イルムにおいても $\mathrm{D}=0.8$ より $\mathrm{D}=1.3$ の 場合が大きくなっている.

\section{2-2 X線写真モトル}

$\mathrm{X}$ 線写真モトル $\left(\right.$ 以下, $\mathrm{WS}_{\mathrm{r}}$ )の変化 は，拈もにスクリーンモトル(以下， $\left.\mathrm{WS}_{\mathrm{s}}\right)$ の増加と考えられる。 そこで, $\mathrm{WS}_{\mathrm{r}}$ から $\mathrm{WS}_{\mathrm{f}}$ の值 を減算してWS $\mathrm{s}$ 求めた。前述のフィルム粒状度と同 様に, 2.0cycles $/ \mathrm{mm}$ のWS 值において, 標準処理を基
Table 1 Relative exposure with the extended-cycle process on the basis of exposure with the standard-cycle process $\left(34^{\circ} \mathrm{C}-90 \mathrm{~s}\right)$.

\begin{tabular}{c|c|c|c|c}
\hline \hline Screen/film & Density & $30^{\circ} \mathrm{C}-210 \mathrm{~s}$ & $32^{\circ} \mathrm{C}-150 \mathrm{~s}$ & $34^{\circ} \mathrm{C}-210 \mathrm{~s}$ \\
\hline M-150/New CM & 0.8 & 0.80 & 1.04 & 0.64 \\
& 1.3 & 0.80 & 1.04 & 0.63 \\
\hline UM MAMMO & 0.8 & 0.80 & 1.00 & 0.63 \\
Fine/UM-MA HC & 1.3 & 0.78 & 1.00 & 0.63 \\
\hline \multirow{2}{*}{ Min R 2000/Min R 2000 } & 0.8 & 1.00 & 0.80 & 0.80 \\
& 1.3 & 1.00 & 0.78 & 0.78 \\
\hline \multirow{2}{*}{ Min-R Medium/Min-R M } & 0.8 & 0.80 & 1.00 & 0.80 \\
& 1.3 & 0.64 & 0.80 & 0.50 \\
\hline
\end{tabular}
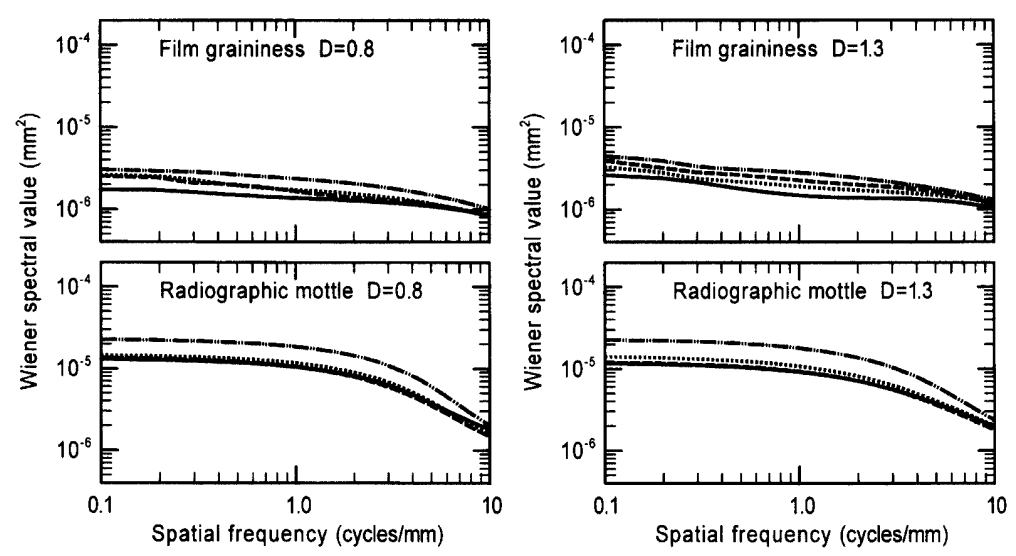

$-34^{\circ} \mathrm{C}-90 \mathrm{~s} \quad \cdots \cdot \cdots \cdot \cdot 30^{\circ} \mathrm{C}-210 \mathrm{~s}$

Fig. 1 Wiener spectra of film graininess and radiographic mottle of M-150/ New CM.
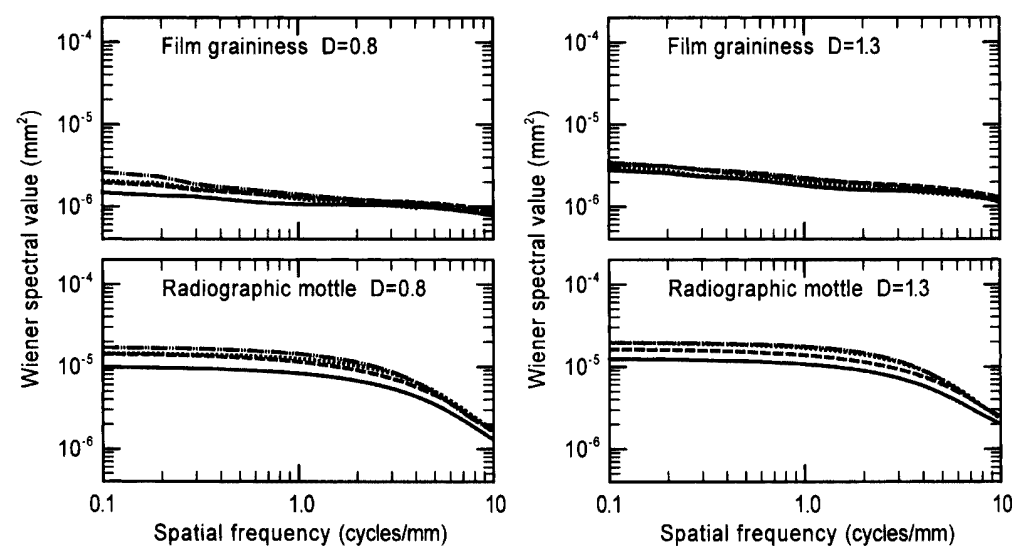

$34^{\circ} \mathrm{C}-90 \mathrm{~s} \quad \cdots \cdot \cdots \cdot \cdot 30^{\circ} \mathrm{C}-210 \mathrm{~s}$

Fig. 2 Wiener spectra of film graininess and radiographic mottle of UM MAMMO Fine/UM-MA HC. 準にしたextended-cycle processの増加率をFig. 6に示 した.Fig. 5 と同様に処理時間，現像温度をそれぞれ グラフの横軸，縦軸として，マーカの直徍に増加率を 


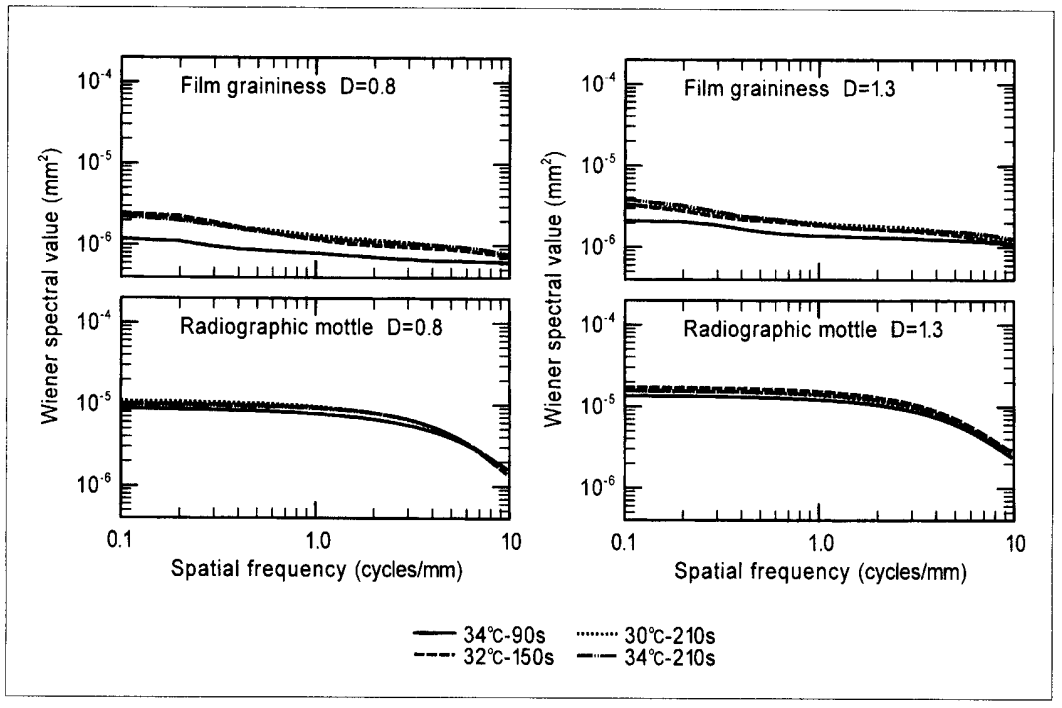

Fig. 3 Wiener spectra of film graininess and radiographic mottle of Min-R 2000/Min-R 2000.

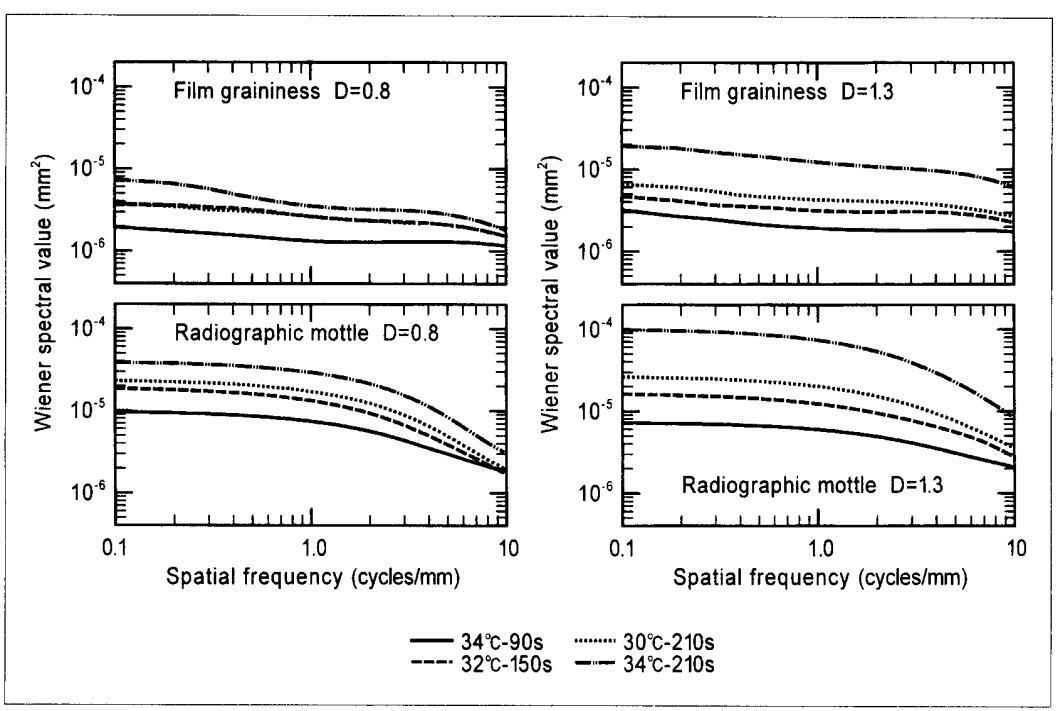

Fig. 4 Wiener spectra of film graininess and radiographic mottle of Min-R Medium/Min-R M.

対応させた。この場合も $30^{\circ} \mathrm{C}-90 \mathrm{~s}$ の増加率のマーカ や標準処理のWS、值を参考に付け加えた。まず，M150/New CMでは両濃度とも $34^{\circ} \mathrm{C}-210 \mathrm{~s}$ の増加率が最 大值を示した。ただしこのシステムの場合， $\mathrm{D}=0.8$, 1.3 の， $32^{\circ} \mathrm{C}-150 \mathrm{~s}$ では，増加率は $0.95 ， 0.89$ になり標 準処理よりWS、值は下がる。これは，Table 1に示した ように露光条件を増加させた影響が現れていると考え られる。 UM MAMMO Fine/UM-MA HCでは, $34^{\circ} \mathrm{C}$ $-210 \mathrm{~s}$ の増加率が最大值を示すが， $30^{\circ} \mathrm{C}-210 \mathrm{~s}$ の場合 も比較的近い值を示した. Min-R 2000/Min-R 2000の 増加率は, $\mathrm{D}=1.3,32^{\circ} \mathrm{C}-150 \mathrm{~s}$ で最大值1.24を示す. この值は，各システムの持つ最大増加率の中で最も低 い值である。一方，最もWS 值の増加が大きく現れた システムはMin-R Medium/Min-R Mであり，増加率は 1.59以上になった。特に, $\mathrm{D}=1.3,34^{\circ} \mathrm{C}-210 \mathrm{~s}$ の $\mathrm{ex}$ - tended-cycle processにおける増加は著 しい.

以上の結果, X線写真モトルは, 上記のスクリーンモトルと前述のフ イルム粒状度の增加により, $10 \mathrm{cycles} / \mathrm{mm}$ までのWS $\mathrm{r}_{\mathrm{r}}$ 変化はFig. 1〜4のようになる。ここでTable 2に 2.0cycles/mmにおけるX線写真モトル の増加分に対するスクリーンモトル とフィルム粒状度の増加分が占める 割合，すなわち増加内訳を示す。

Min-R 2000/Min-R 2000の D=1.3, $30^{\circ} \mathrm{C}-210 \mathrm{~s} に$ 拀いては，フィルム粒 状度の増加分がX線写真モトルの増 加分の $40 \%$ を占めるに至っている が，いずれのシステムに扔いてもス クリーンモトルの増加分が占める割 合は大きい。さらに, Fig. 5，6と同 様に2.0cycles/mmに扔けるWS r 值を， 標準処理に対する增加率でFig. 7に示 した. Table 2で示したように，スク リーンモトルが増加内訳に执いても 支配的であることから，Fig. 7はFig. 6に類似した増加傾向を示す。

\section{3. 考 察}

\section{3-1 フィルム粒状度}

extended-cycle processはいずれのフ イルムに対してもフィルム粒状度, WStを増加させた．New CMのスクリ ーンモトル，WS が減少する $32^{\circ} \mathrm{C}$ $150 \mathrm{~s}$ の場合にも WS tended-cycle processの影響を $\mathrm{WS}_{\mathrm{f}}$ の増 加率でみると，対象にしたフィルムの中でUM-MA HCが最も影響が少なく, Min-R Mが最も大きな影響 を受けた。また，Min-R 2000では，Fig.5に示したWS の増加率は $\mathrm{D}=1.3$ より $\mathrm{D}=0.8$ の場合が明らかに大き く, 他のフィルムの傾向と異なった。 ただし, 標準処 理に抢ける $\mathrm{D}=0.8$ のS が他のフィルムより小さいこ とが増加率を高くしており, extended-cycle processの WS は，標準処理のUM-MA HCとほぼ同等のレベル になる，以上のようにextended-cycle processにおいて は，フィルム粒状性の悪化は避けられないといえる。 また, フィルム粒状度において濃度ゆらぎのWSの断 面は，低濃度領域では理論的に導出できることが知ら れて抢り, その值は, ほぼ平均濃度, 粒子の面積に比 例する ${ }^{13,14)}$.このことを参考にすれば，現像銀粒子の 大きさはextended-cycle processにより増大しているこ 


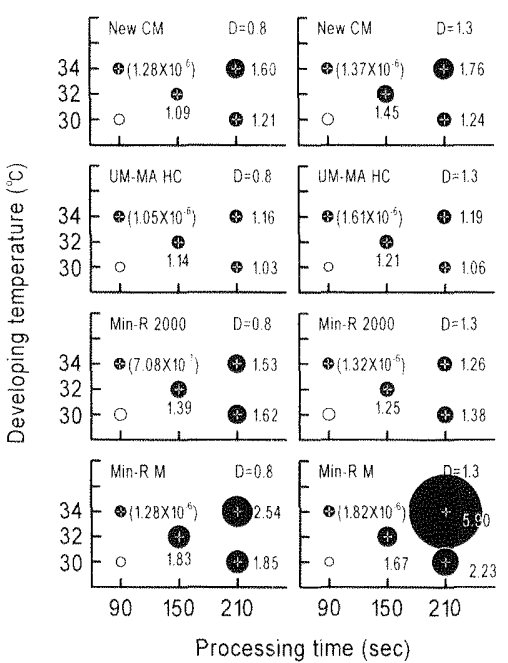

Rate of an increase in Wiener spectral value of film graininess

Rate of an increase in Wiener spectral value of film graininess at $30^{\circ} \mathrm{C}-90 \mathrm{~s}$ for reference

Fig. 5 Changes in Wiener spectral values of film graininess at 2.0 cycles $/ \mathrm{mm}$ with processing time and developing temperature. These Wiener spectral values are shown as rates of increase on the basis of values with the standard-cycle process $\left(34^{\circ} \mathrm{C}-\right.$ $90 \mathrm{~s}$ ). Each diameter of the marker corresponds to the rate of increase in the Wiener spectral value added to the graph. The value in parentheses in the graph is the Wiener spectral value $\left(\mathrm{mm}^{2}\right)$ with the standard-cycle process.

とが推測される。

次に，X線写真モトルに対するフィルム粒状度の割 合，つまり寄与率をFig. 1〜4のWS值より算出した。 さらに, extended-cycle processがフィルム粒状度に与 える増加の評価指標として，寄与率が50\%，すなわち フィルム粒状度がスクリーンモトルと同等にX線写真 のノイズ特性に影響を及ぼす空間周波数を調べTable 3 に示す. UM MAMMO Fine/UM-MA HCでは，スク リーンモトルの増加が大きいため，寄与率50\%の空間 周波数は高周波数側に移動したがM-150/New CM,

Min-R 2000/Min-R 2000, Min-R Medium/Min-R Mで は低周波数側に移動する場合がある。特に $\mathrm{D}=1.3$ ， Min-R Medium/Min-R Mにおいては，標準処理の夸与 率 $50 \%$ の空間周波数は 3.9 cycles $/ \mathrm{mm}$ と比較的低周波数 であるが, extended-cycle processの寄与率50\%の空間 周波数は，さらに低い值を示し $32^{\circ} \mathrm{C}-150 \mathrm{~s}$ においては 2.9cycles $/ \mathrm{mm}$ になった. extended-cycle process $の$ 寄与. 率 $50 \%$ が低㓮波数側に移動しても5.0cycles $/ \mathrm{mm}$ 以上の 高周波域である他のシステムに比較して， $\mathrm{D}=1.3$, $32^{\circ} \mathrm{C}-150$ s Min-R Medium/Min-R Mでは, フィルム 粒状度の影響が顕著に現れると考えられる。

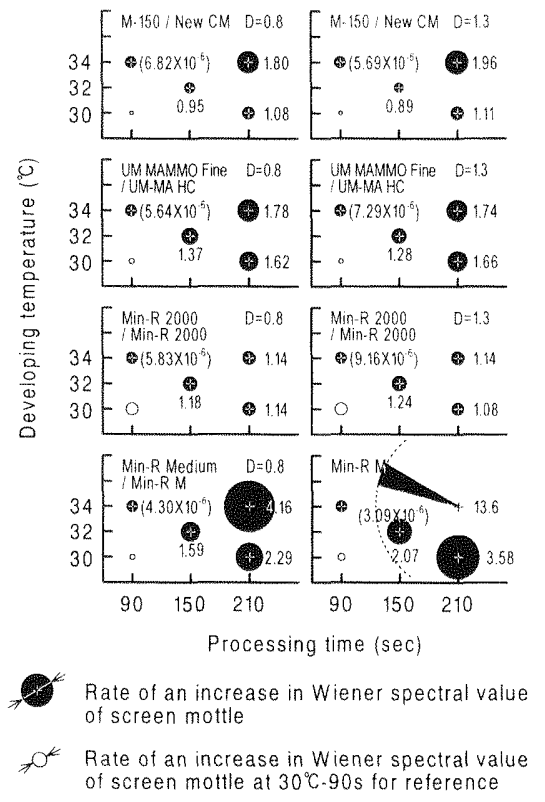

Fig. 6 Changes in Wiener spectral values of screen mottle at $2.0 \mathrm{cycles} / \mathrm{mm}$ with processing time and developing temperature. These Wiener spectral values are shown as rates of increase on the basis of the value with the standard-cycle process $\left(34^{\circ} \mathrm{C}-90 \mathrm{~s}\right)$. Each diameter of the marker corresponds to the rate of increase in the Wiener spectral value added to the graph. The value in parentheses in the graph is the Wiener spectral value $\left(\mathrm{mm}^{2}\right)$ with the standard-cycle process.

\section{3-2 X線写真モトル}

extended-cycle processによるX線写真モトル, WS 倠の増加が小さいシステムは，M-150/New CMで $32^{\circ} \mathrm{C}$ - 150sとなる. しかし，システム感度が標準処理より 低くなり，Table 1に示したように露光量を増加させて いる.さらにこれは, 患者被曝線量の増加につながる ことから, 比較の対象から除外すると, Min-R 2000/ Min-R 2000が最も影響の少ないシステムといえる.こ のシステムはTable 1に示したように，露光条件は最大 で20\%程度の減少に留まっている。さらに，Min-R 2000のグラディエントはextended-cycle processを行っ ても上昇しないことが，この結果のおもな要因になっ ていると考えられる。参考に，センシトメータを用い たデータであるが，本論文の各フィルムに該当するグ ラデイエントを文献7)加抜粋してFig. 8に示す。一 方, extended-cycle process W $\mathrm{W}_{\mathrm{r}}$ 值の増加が最も大き いMin-R Mは, Fig. 8のようにグラディエントの増加 が大きく，さらにTable 1に示した露光条件は最大で50 \%程度まで減少する。

ここで，量子モトルとともにスクリーンモトルのも う一つの構成要素である増感紙の構造モトルは，だい たい蛍光体粒子径にだけ依存する15) とすれば，Fig. 6 
Table 2 Rates for which increments in screen mottle and film graininess account for the increment in radiographic mottle at 2.0 cycles $/ \mathrm{mm}$.

\begin{tabular}{|c|c|c|c|c|}
\hline Screen/film & Density & $\begin{array}{l}\text { Dev.Temp.- } \\
\text { Proc.Time }\end{array}$ & $\begin{array}{c}\text { Film } \\
\text { graininess }\end{array}$ & $\begin{array}{l}\text { Screen } \\
\text { mottle }\end{array}$ \\
\hline \multirow{2}{*}{ M-150/New CM } & 0.8 & $\begin{array}{l}30^{\circ} \mathrm{C}-210 \mathrm{~s} \\
32^{\circ} \mathrm{C}-150 \mathrm{~s} \\
34^{\circ} \mathrm{C}-210 \mathrm{~s}\end{array}$ & $\begin{array}{c}31.9 \\
- \\
12.4\end{array}$ & $\begin{array}{c}68.1 \\
- \\
87.6\end{array}$ \\
\hline & 1.3 & $\begin{array}{l}30^{\circ} \mathrm{C}-210 \mathrm{~s} \\
32^{\circ} \mathrm{C}-150 \mathrm{~s} \\
34^{\circ} \mathrm{C}-210 \mathrm{~s}\end{array}$ & $\begin{array}{c}34.0 \\
- \\
16.0\end{array}$ & $\begin{array}{c}66.0 \\
- \\
84.0\end{array}$ \\
\hline \multirow{2}{*}{$\begin{array}{l}\text { UM MAMMO } \\
\text { Fine / UM- } \\
\text { MA HC }\end{array}$} & 0.8 & $\begin{array}{l}30^{\circ} \mathrm{C}-210 \mathrm{~s} \\
32^{\circ} \mathrm{C}-150 \mathrm{~s} \\
34^{\circ} \mathrm{C}-210 \mathrm{~s}\end{array}$ & $\begin{array}{l}0.9 \\
6.5 \\
3.8\end{array}$ & $\begin{array}{l}99.1 \\
93.5 \\
96.2\end{array}$ \\
\hline & 1.3 & $\begin{array}{l}30^{\circ} \mathrm{C}-210 \mathrm{~s} \\
32^{\circ} \mathrm{C}-150 \mathrm{~s} \\
34^{\circ} \mathrm{C}-210 \mathrm{~s}\end{array}$ & $\begin{array}{r}1.9 \\
14.1 \\
5.2\end{array}$ & $\begin{array}{l}98.1 \\
85.9 \\
94.8\end{array}$ \\
\hline \multirow{2}{*}{$\begin{array}{l}\text { Min R 2000/ } \\
\text { Min R } 2000\end{array}$} & 0.8 & $\begin{array}{l}30^{\circ} \mathrm{C}-210 \mathrm{~s} \\
32^{\circ} \mathrm{C}-150 \mathrm{~s} \\
34^{\circ} \mathrm{C}-210 \mathrm{~s}\end{array}$ & $\begin{array}{l}34.9 \\
21.3 \\
30.8 \\
\end{array}$ & $\begin{array}{l}65.1 \\
78.7 \\
69.2 \\
\end{array}$ \\
\hline & 1.3 & $\begin{array}{l}30^{\circ} \mathrm{C}-210 \mathrm{~s} \\
32^{\circ} \mathrm{C}-150 \mathrm{~s} \\
34^{\circ} \mathrm{C}-210 \mathrm{~s}\end{array}$ & $\begin{array}{l}40.4 \\
13.0 \\
21.1\end{array}$ & $\begin{array}{l}59.6 \\
87.0 \\
78.9 \\
\end{array}$ \\
\hline \multirow{2}{*}{$\begin{array}{c}\text { Min-R Medium/ } \\
\text { Min-R M }\end{array}$} & 0.8 & $\begin{array}{l}30^{\circ} \mathrm{C}-210 \mathrm{~s} \\
32^{\circ} \mathrm{C}-150 \mathrm{~s} \\
34^{\circ} \mathrm{C}-210 \mathrm{~s}\end{array}$ & $\begin{array}{l}16.3 \\
29.5 \\
12.6\end{array}$ & $\begin{array}{l}83.7 \\
70.5 \\
87.4 \\
\end{array}$ \\
\hline & 1.3 & $\begin{array}{l}30^{\circ} \mathrm{C}-210 \mathrm{~s} \\
32^{\circ} \mathrm{C}-150 \mathrm{~s} \\
34^{\circ} \mathrm{C}-210 \mathrm{~s}\end{array}$ & $\begin{array}{l}21.9 \\
27.1 \\
18.7\end{array}$ & $\begin{array}{l}78.1 \\
72.9 \\
81.3\end{array}$ \\
\hline
\end{tabular}

unit: \%

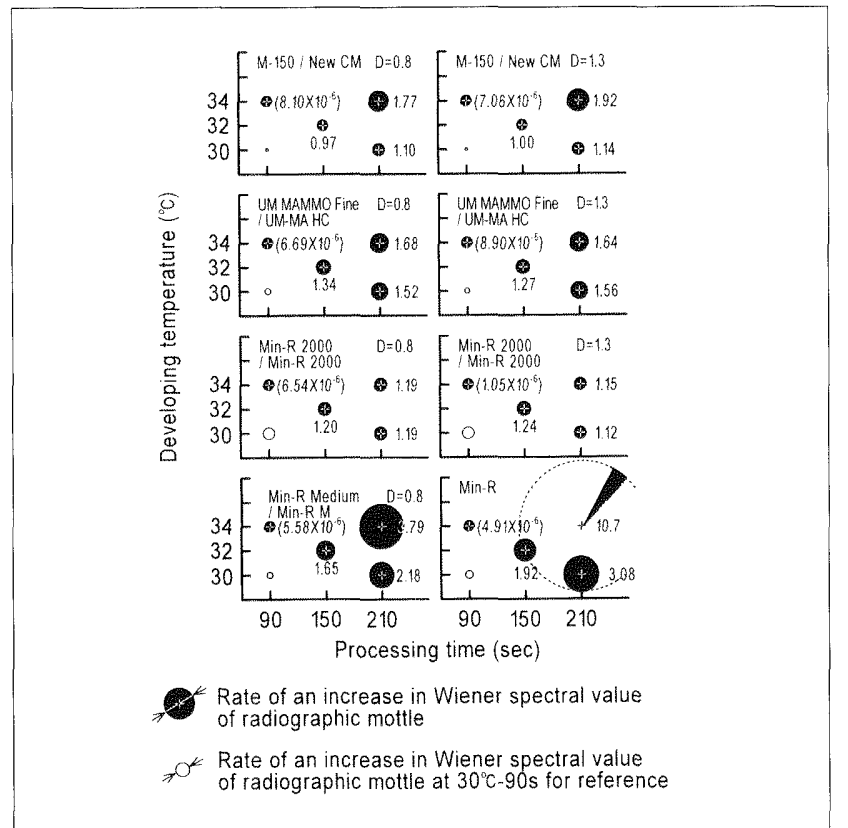

Fig. 7 Changes in Wiener spectral values of radiographic mottle at 2.0 cycles $/ \mathrm{mm}$ with processing time and developing temperature. These Wiener spectral values are shown as rates of increase on the basis of values with the standard-cycle process $\left(34^{\circ} \mathrm{C}-\right.$ $90 \mathrm{~s})$. Each diameter of the marker corresponds to the rate of increase in the Wiener spectral value added to the graph. The value in parentheses in the graph is the Wiener spectral value $\left(\mathrm{mm}^{2}\right)$ with the standard-cycle process.

Table 3 Spatial frequencies at a $50 \%$ contribution rate of film graininess to radiographic mottle.

\begin{tabular}{c|c|c|c|c|c}
\hline \hline Screen/film & Density & $34^{\circ} \mathrm{C}-90 \mathrm{~s}$ & $30^{\circ} \mathrm{C}-210 \mathrm{~s}$ & $32^{\circ} \mathrm{C}-150 \mathrm{~s}$ & $34^{\circ} \mathrm{C}-210 \mathrm{~s}$ \\
\hline \multirow{2}{*}{ M-150/New CM } & 0.8 & $>10$ & 9.7 & 8.1 & 9.9 \\
& 1.3 & 9.3 & 7.5 & 6.0 & 8.9 \\
\hline UM MAMMO Fine & 0.8 & 8.6 & $>10$ & 9.2 & $>10$ \\
/UM-MA HC & 1.3 & 8.3 & 10.0 & 9.3 & $>10$ \\
\hline Min R 2000 & 0.8 & $>10$ & 10.0 & $>10$ & 9.1 \\
Min R 2000 & 1.3 & $>10$ & $>10$ & $>10$ & 9.6 \\
\hline Min-R Medium & 0.8 & 6.3 & 5.9 & 4.8 & 7.4 \\
Min-R M & 1.3 & 3.9 & 7.0 & 2.9 & 6.4 \\
\hline
\end{tabular}

unit: cycles/mm

またはFig.7の増加傾向は, extended-cycle processに よるシステムのコントラスト, 感度などの変化の組み 合わせ結果を扔もにみているにほかならない. なお, 正確には，MTFもかかわっており, extended-cycle processを行うと多少MTFの低下があると思われる(6).

\section{3-3 トレンド}

現像の温度, 時間の影響とは別に, extended-cycle processはフィルムがローラと接触する時間が長くなる ことから，トレンドの原因となる現像むらやローラマ
一クなどが大きくなる可能性が 考えられる。そして，これらの 影響は低空間周波数域で現れ る。そこで，まず標準処理およ びextended-cycle process $の W S$ より $0.1 \sim 0.5 \mathrm{cycle} / \mathrm{mm}$ の平均値 を求め, 低空間周波数の值とし た．さらに，標準処理に対する extended-cycle process $の$ 低空間 周波数揖よび2.0cycles $/ \mathrm{mm} に お ~$ けるWS の増加量を算出した。 その結果をTable 4に示すとと もに低空間周波数打よび 2.0cycles $/ \mathrm{mm}$ のWS の増加量を比較した。これは，31項でも触れたが，WS は，理論的に導出でき，0＼cjkstart数 十cycles/mmでは一定の值とみなせる，すなわち空間 周波数により変化しないことに基づいたものである. 実際のフィルムでは，厳密にはWS は一定にならず77， また実際の黑化銀の分布は，三次元的に広がり，完全 にランダムに分布していないなど，理論モデルとの差 異があるとされている13.14).なお，トレンド処理は， extended-cycle processによる試料に対しても標準処理 と同じ条件で行っている. 
その結果，いずれのフィルムにおいても2.0cycles/ $\mathrm{mm}$ より低空間周波数において, extended-cycle processのWS の増加量が大きくなる傾向が認められた。 また, $34^{\circ} \mathrm{C}-210 \mathrm{~s}$ の場合に, その傾向が大きいといえ るが，すべてのフィルムにあてはまらない。自動現像 機のローラの状態は非常に微妙な問題であり，その影 響は必ずしも明瞭に出てこないと思われる．ただし， トレンド処理によりローラマークや濃度むらなどが適 切に除去されているとすれば， $\mathrm{WS}_{\mathrm{f}}$ の増加傾向の原因 は, 以下のような現象との関連が考えられる。extended-cycle processによる黑化銀粒子の大きさの増大 に加え，その分布が三次元的に拡がり，完全にランダ ムに分布していないこと。また, extended-cycle processでは处理時間の延長から，これらの現像銀粒子の 大きさ・構造や分布が，その後の過程での乳剂膜の膨 張や収縮に伴って変化することなども挙げられる ${ }^{18)}$.

さらに，これらのことはスクリーンモトルを低空間 周波数域で算出する場合，別々に作成するX線写真モ トル，フィルム粒状度用の試料に同等のトレンドなど の影響がないと誤差を生むことになる，ただ，Table 4 から分かるように低空間周波数と高空間周波数の違い は, Min-R Medium/Min-R M $\left(\mathrm{D}=0.8 ， 34^{\circ} \mathrm{C}-210 \mathrm{~s}\right)$ を 除くとX線写真モトルやスクリーンモトルのWS值よ り一桁少ない場合がほとんどであり，10\%程度の誤差 に留まると考えられる．以上，さらに詳細な検討は必

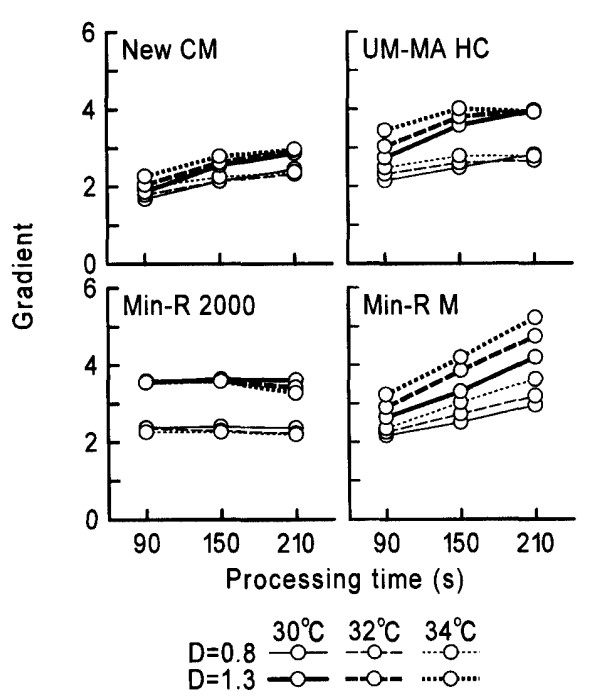

Fig. 8 Gradients at densities of 0.8 and 1.3 plotted versus processing time at each developing temperature. The gradients were obtained from characteristic curves of films exposed by a sensitometer. ${ }^{7)}$

要であるが，少なくともextended-cycle processにより 2.0cycles/mmに比較して低空間周波数のWS 值の増加 が大きくなる傾向が認められた。

なお，すでにNew CMは，CM-Hに替わっている. CM-Hに対する予備実験では，UM-MA HCとNew CM の中間程度にextended-cycle processの影響が現れると

Table 4 Comparison between 0.1-0.5 and $2.0 \mathrm{cycles} / \mathrm{mm}$ in the increment in the Wiener spectral value of film graininess by extended-cycle process. The values in this table were obtained by subtracting the Wiener spectral values for the standard-cycle process from those for the extendedcycle process, at $0.1-0.5$ and 2.0 cycles $/ \mathrm{mm}$. The Wiener spectral values of 0.1-0.5 cycles $/ \mathrm{mm}$ were obtained by averaging the Wiener spectral values from 0.1 to $0.5 \mathrm{cycles} / \mathrm{mm}$.

\begin{tabular}{|c|c|c|c|c|c|}
\hline Screen/film & Density & cycles/mm & $30^{\circ} \mathrm{C}-210 \mathrm{~s}$ & $32^{\circ} \mathrm{C}-150 \mathrm{~s}$ & $34^{\circ} \mathrm{C}-210 \mathrm{~s}$ \\
\hline \multirow{2}{*}{ M-150/New CM } & 0.8 & $\begin{array}{c}0.1-0.5 \\
2.0\end{array}$ & $\begin{array}{l}6.67 \\
2.63\end{array}$ & $\begin{array}{l}5.89 \\
1.11\end{array}$ & $\begin{array}{l}12.1 \\
7.73\end{array}$ \\
\hline & 1.3 & $\begin{array}{c}0.1-0.5 \\
2.0\end{array}$ & $\begin{array}{l}3.86 \\
3.33\end{array}$ & $\begin{array}{l}8.65 \\
6.13\end{array}$ & $\begin{array}{l}14.0 \\
10.4\end{array}$ \\
\hline \multirow{2}{*}{$\begin{array}{l}\text { UM MAMMO Fine } \\
\text { /UM-MA HC }\end{array}$} & 0.8 & $\begin{array}{c}0.1-0.5 \\
2.0\end{array}$ & $\begin{array}{l}4.28 \\
0.30\end{array}$ & $\begin{array}{l}3.55 \\
1.46\end{array}$ & $\begin{array}{l}7.33 \\
1.72\end{array}$ \\
\hline & 1.3 & $\begin{array}{c}0.1-0.5 \\
2.0\end{array}$ & $\begin{array}{l}1.17 \\
0.96\end{array}$ & $\begin{array}{l}4.44 \\
3.39\end{array}$ & $\begin{array}{l}5.26 \\
2.98\end{array}$ \\
\hline \multirow{2}{*}{$\begin{array}{l}\text { Min R } 2000 \\
\text { /Min R } 2000\end{array}$} & 0.8 & $\begin{array}{c}0.1-0.5 \\
2.0\end{array}$ & $\begin{array}{l}7.79 \\
4.41\end{array}$ & $\begin{array}{l}7.71 \\
2.76\end{array}$ & $\begin{array}{l}8.18 \\
3.75\end{array}$ \\
\hline & 1.3 & $\begin{array}{c}0.1-0.5 \\
2.0\end{array}$ & $\begin{array}{l}8.52 \\
5.07\end{array}$ & $\begin{array}{l}7.13 \\
3.33\end{array}$ & $\begin{array}{l}10.5 \\
3.40\end{array}$ \\
\hline \multirow{2}{*}{$\begin{array}{c}\text { Min-R Medium } \\
\text { /Min-R M }\end{array}$} & 0.8 & $\begin{array}{c}0.1-0.5 \\
2.0\end{array}$ & $\begin{array}{l}16.4 \\
10.8\end{array}$ & $\begin{array}{l}17.6 \\
10.6\end{array}$ & $\begin{array}{l}41.1 \\
19.6\end{array}$ \\
\hline & 1.3 & $\begin{array}{c}0.1-0.5 \\
2.0\end{array}$ & $\begin{array}{l}29.3 \\
22.4\end{array}$ & $\begin{array}{l}13.4 \\
12.3\end{array}$ & $\begin{array}{l}140 \\
89.2\end{array}$ \\
\hline
\end{tabular}

unit: $\times 10^{-7} \mathrm{~mm}^{2}$ 
予測している。

\section{4. 結 語}

マンモ用片面増感紙片面乳剤フィルムシステム,

M-150/New CM, UM MAMMO Fine/UM-MA HC, Min-R 2000/Min-R 2000, Min-R Medium/Min-R Mに おいてextended-cycle processがX線写真のノイズ特性 に及ぼす影響をWSの測定より調べた。以下に得られ た標準処理との比較結果を要約する。

\section{4-1 フィルム粒状度}

いずれのフィルムもWS值は増加した，Min-R Mに 最も大きく影響が現れ，2.0cycles $/ \mathrm{mm}$ の増加率は 1.67 以上になった。また，影響が最も小さく出たフィルム はUM-MA HCであり，その増加率は1.03〜1.21であっ た。また，フィルム粒状度の寄与率 $50 \%$ の空間周波数 は，標準処理より低周波数になる場合があった。

\section{4-2 X線写真モトル}

WS值の増加結果のみ取り上げると, Min-R Mに最 も大きく影響が現れ，2.0cycles $/ \mathrm{mm} の$ 増加率は1.65以 上になった。また，影響が最も小さく出たシステムは
Min-R 2000/Min-R 2000であり，その増加率は1.12 1.24であった。

\section{4-3 トレンド}

標準現像抢よびextended-cycle processにおける共通 のトレンド処理を行ったフィルム粒状度の測定結果を 用いて調べた。 その結果, WS值の増加は2.0cycles/ $\mathrm{mm}$ に比較して低空間周波数域 $(0.1 \sim 0.5 \mathrm{cycle} / \mathrm{mm})$ で 大きくなる傾向が認められた. 現像むらやローラマー クなどの影響の増加とともに黒化銀の大きさ・構造や 分布の変化が原因として考えられる。

\section{謝 辞}

今回の研究にあたり貴重な助言をいただいた広島県 立保健福祉短期大学 吉田 彰氏をはじめ医用画像情 報研究会の皆様に深謝いたします。

なお，本論文は，日本放射線技術学会第53回総会学 術大会 (平成 9 年 4 月, 横浜)で発表した内容の一部 に，追加実験の結果を加えまとめたものである.

\section{参考文献}

1) Kimme-Smith C, Rothschild PA, Bassett LW, et al.: Mammographic film-processor temperature, development time, and chemistry: Effect on dose, contrast, and noise. Am J Roentgenol, 152, 35-40, (1989).

2) Tabar $L$ and Haus AG: Processing of mammographic films: Technical and clinical considerations. Radiology, 173, 6569, (1989).

3) Haus AG: State of the art screen-film mammography: A technical overview. Screen Film Mammography, Imaging Considerations and Medical Physics Responsibilities. pp.1-46, Medical Physics Publishing, Madison Wisconsin, (1991).

4) Kimme-Smith C: Mammography screen-film selection, film exposure and processing. Screen Film Mammography, Imaging Considerations and Medical Physics Responsibilities. pp.135-158, Medical Physics Publishing, Madison Wisconsin, (1991).

5) Brink C, JFK de Villiers, Lötter MG, et al.: The influence of film processing temperature and time on mammographic image quality. Br J Radiol, 66 (788), 685-690, (1993).

6) Haus AG: Screen-film image receptors and film processing. Syllabus: A Categorical Course in Physics Technical Aspects of Breast Imaging, Third Edition. pp.85-101, RSNA Publications, Oak Brook Illinois, (1994).

7) 丸山敏則, 後藤佐知子, 東 義晴, 他：マンモグラフィ用 フィルムに扔けるextended-cycle process の基礎的研究一コ ントラスト, 相対感度一, 日放技学誌, 53(11)，16971704, (1997).

8) Rossmann K: Spatial fluctuations of $x$-ray quanta and the recording of radiographic mottle. Am J Roentgenol, 90 (4), 863-869, (1963).

9）後藤佐知子, 東 義晴, 丸山敏則, 他：マンモグラフィ用
フィルムにおけるフィルム粒状度の測定. 日放技学誌, 55 (11), 1115-1121, (1999).

10) Tanner RL and Hendrick ER: Current status of the American college of radiology mammography screening accreditation program. Screen Film Mammography, Imaging Considerations and Medical Physics Responsibilities. pp.221-242, Medical Physics Publishing, Madison Wisconsin, (1991).

11 ) 小寺吉衞, 大久敏弘, 田中 勲, 他 : 放射線画像系の粒状 性の測定法 (I)，日放技学誌，43(12)，1743-1768， (1987).

12) 小寺吉衞, 大久敏弘, 田中 勲, 他: 放射線画像系の粒状 性の測定法(II)。日放技学誌，44(1)，44-62，(1988).

13) 内田 勝, 金森仁志, 稲津 博：ゆらぎの理論. 放射線画 像情報工学 (II), pp.182-202, 通商産業研究社, 東京, (1982).

14) Dainty JC and Shaw R: Input/output relationships for conventional photographic processes: Experimental observables. Image Science, pp.53-67, Academic Press, New York, (1974).

15) 内田 勝, 金森仁志, 稲津 博：放射線領域への適用 (I). 放射線画像情報工学 (I). pp.282-293, 通商産業研究社, 東 京, (1988).

16) 丸山敏則, 後藤佐知子, 東 義晴, 他：マンモグラフィに おけるExtended-cycle Process と低感度システム一描出能向 上と被曝低減への試み一。日本放射線技術学会第54回総会 学術大会一般研究発表㣪抄録, 85，(1998).

17）東田善治, 吉田 章, 勝田 昇, 他: 胸部撮影のための新 しい増感紙一フィルム系の画像特性. 日放技学誌，52 (4), 524-529, (1996).

18) 山田 稔: 現像の化学. 新しい放射線写真学, pp.99-131, 富士メディカルシステム株式会社，東京，（1998）. 
Fig. 1 M-150/New CMのフィルム粒状度およびX線写真モトルのウィナースペクトル。

Fig. 2 UM MAMMO Fine/UM-MA HCのフィルム粒状度拉よびX線写真モトルのウィナースペクトル。

Fig. 3 Min-R 2000/Min-R 2000のフィルム粒状度执よびX線写真モトルのウィナースペクトル。

Fig. 4 Min-R Medium/Min-R Mのフィルム粒状度およびX線写真モトルのウィナースペクトル.

Fig. 52.0 cycles/mmにおけるフィルム粒状度のウィナースペクトル值の処理時間㧍よび現像温度による変化. これらのウィナー スペクトル值は，標準処理 $\left(34^{\circ} \mathrm{C}-90 \mathrm{~s}\right)$ の值を基準に増加率として示されている.マーカの各直径は，グラフに追加された ウイナースペクトルの増加率に対応する。グラフ中の括弧の值は標準処理のウィナースペクトルの值 $\left(\mathrm{mm}^{2}\right)$ である.

Fig. 6 2.0cycles/mmに拈けるスリーンモトルのウィナースペクトル值の処理時間抢よび現像温度による変化. これらのウィナ ースペクトル值は，標準処理 $\left(34^{\circ} \mathrm{C}-90 \mathrm{~s}\right)$ の值を基準に増加摔としてホされている。マーカの备直径は，グラフに追加され たウィナースペクトルの増加率に対迈する．グラフ中の括弧の值は標準処理のウィナースペクトルの值 $\left(\mathrm{mm}^{2}\right)$ である.

Fig. 72.0 cycles/mmにおけるX線写真モトルのウィナースペクトル值の処理時間および現像温度による変化. これらのウィナース ペクトル值は，標準処理 $\left(34^{\circ} \mathrm{C}-90 \mathrm{~s}\right)$ の值を基準に増加率としてホされている. マーカの备直径は，グラフに追加されたウ イナースペクトルの増加率に対応する。グラフ中の括弧の嗔は標準処理のウィナースペクトルの值 $\left(\mathrm{mm}^{2}\right)$ である.

Fig. 8 各現像温度での濃度 0.8 と1.3のグラディエント対処理時間. グラディエントは, 感光計によって露光されたフィルムの特性 曲線から求められだ!

Table 1 標準処理 $\left(34^{\circ} \mathrm{C}-90 \mathrm{~s}\right)$ の露光量を基準にしたextended-cycle processの相対露光量.

Table $22.0 \mathrm{cycles} / \mathrm{mm}$ に扮けるX線写真モトルの増加分に対寸るスクリーンモトルとフィルム粒状度の增加分が占める割合.

Table 3 X線写真モトルへのフィルム精状度の寄与率50パーセントの空間周波数.

Table 4 extended-cycle processによるフィルム粒状度のウィナースペクトル値の増加量に関する0.1 0.5と $2.0 \mathrm{cycles} / \mathrm{mm} の$ 比較. この表の值は $0.1 〜 0.5$ と 2.0 cycles $/ \mathrm{mm}$ でextended-cycle processのウィナースペクトル值から標準処理のそれらを引き算する こにより得られた。

0.1 0.5cycle $/ \mathrm{mm}$ ウィナースペクトル值は， $0.1 〜 0.5 \mathrm{cycle} / \mathrm{mm}$ までのウィナースペクトル值の平均より求めた. 